\title{
StSL8 Oo!XəW MəN'SOUEIV SOT
}

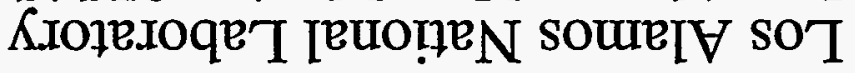

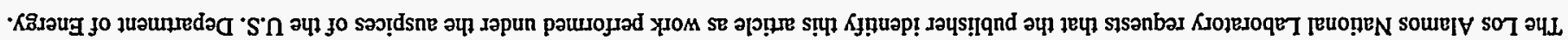

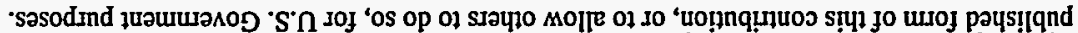

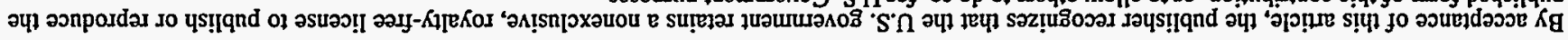

\author{
966I Krenuer

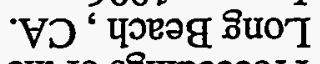

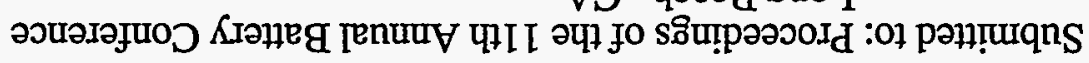

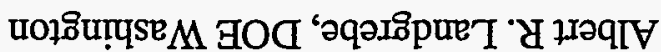

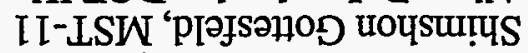

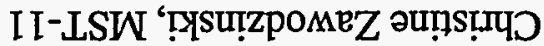

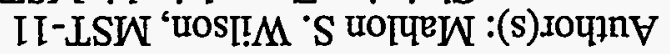

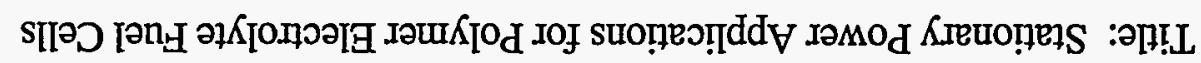

1280

co: $9: 58$

$=\div, 2=0$

-

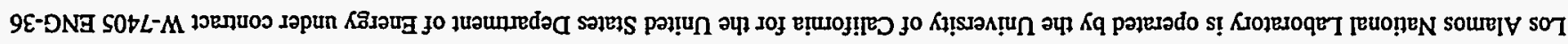




\title{
Stationary Power Applications for Polymer Electrolyte Fuel Cells
}

\author{
Mahlon S. Wilson, ${ }^{a}$ Christine Zawodzinski, ${ }^{a}$ Shimshon Gottesfeld, a and Albert R. Landgrebe

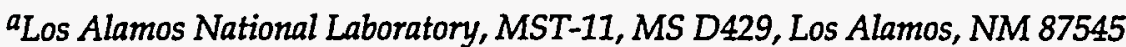 \\ bu. S. Dept. of Energy, Forrestal Building, 1000 Independence Ave., SW, Washington D.C. 20585
}

\begin{abstract}
The benefits provided by Polymer Electrolyte Fuel Cells (PEFC) for power generation (e.g. low operating temperatures, and non-corrosive and stable electrolyte), as well as advances in recent years in lowering their cost and improving anode poisoning tolerance, are stimulating interest in the system for stationary power applications. A significant market potentially exists for PEFCs in certain stationary applications where PEFC technology is a more attractive alternative to other fuel cell technologies. A difficulty with the PEFC is its operation on reformed fuels containing $\mathrm{CO}$, which poisons the anode catalyst. This difficulty can be alleviated in several ways. One possible approach is described whereby the product reformate is purified using a relatively low cost, high-throughput hydrogen permselective separator. Preliminary experiments demonstrate the utility of the concept.
\end{abstract}

\section{Introduction}

Fuel cell technologies provide a means to generate power at high energy efficiency with minimal environmental emissions. These benefits have fostered great interest in fuel cell technologies for utility, customer-side-of-the-meter, and transportation applications. Federal and private industrial support to develop fuel cell technologies has been ongoing for three decades. Much of the research has focused on the development of phosphoric acid (PAFC), molten carbonate (MCFC), and solid oxide fuel cell (SOFC) technologies. To date, the PAFC system has reached the stage of commercial demonstration for both utility and stand-alone applications, while MCFC and SOFC systems are only now entering the demonstration phase.

Polymer electrolyte fuel cells (PEFC) have been successfully implemented for aerospace applications, and to a varying extent are touted for transportation applications. Until recently, however, they have not been seriously considered for utility and/or standalone applications for a number of reasons. In the past, the application of the PEFC for terrestrial applications was not considered viable because of its high cost (primarily due to high $\mathrm{Pt}$ loadings) and its sensitivity to low levels of $\mathrm{CO}$ in reformed carbonaceous fuel streams. Both of these barriers for implementation of PEFCs in utility and/or stand alone applications have been significantly lowered in the last few years, to some extent as a result of work done at Los Alamos National Laboratory. These and other technical developments are now positioning the PEFC as a viable and attractive alternative for some utility and stand-alone applications (1-3).

\section{Stationary Power Applications}

While the large utility applications are envisioned as belonging to the MCFC and SOFC, there are many applications such as utility peak power generation, demand-side-management, and dispersed power generation for which the PAFC and PEFC are probably more attractive options. In these cases, the PEFC will probably compete directly with the PAFC. The PEFC appears to have a major advantage over PAFC technology in terms of stack efficiency (higher voltage at same current density) and power density, however, the total system efficiency may be not very different because the waste heat of the PAFC can be used to generate reformer steam. The long-term cost of the PEFC technology could be more favorable, especially in light of recent advancements. Additionally, the reliability and longevity of the PEFC may be superior due to the relative stability and inertness of the pseudo-solid electrolyte compared to phosphoric acid. Thus, the PEFC can effectively compete in many of the near term markets in which the PAFC is expected to be successful. Correspondingly, the following discussions are culled from studies that are oriented towards the latter (4-7).

\section{Utility Applications}

Many applications in the utility sector require capacities in the range of 1 to $10 \mathrm{MW}$. This is

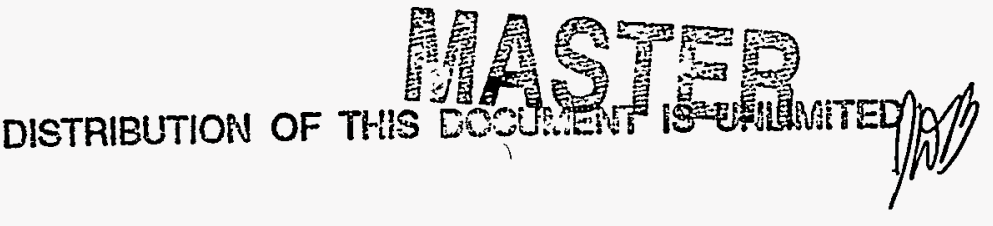


particularly true for some of the small public utility systems that are required to pay high charges for peak demand, which they usually purchase from a private utility grid. A cost-effective fuel cell system would allow them to produce electricity for these peaking applications. These more modest utility applications are more viable for the PEFC and PAFC.

The public power utility segments represent some $14 \%$ of the electric utility industry (measured in kilowatt hour sales to the customer), and $12.5 \%$ of the industry in generating capacity. The public power sector has an installed capacity of approximately $89,000 \mathrm{MW}$ and an additional $18 \%$ of energy is purchased by these entities for peak power. Indications are that at $\$ 1,100 / \mathrm{kW}$, fuel cell technologies could be attractive for peak power requirements. This is an especially attractive cost target for the PEFC. A conservative estimate of this market puts it in the range of 14,000 to $17,000 \mathrm{MW}$ for fuel cells. The efficiency, compact design, low maintenance and potentially lower cost of the PEFC could allow it to capture a substantial portion of this market, which was expected to emerge in the 1995 to 2010 time frame. This near-term market for PEFCs is capable of accepting higher costs for market introduction, and will also provide an opportunity for the manufacturing cost of PEFCs to come down, thus opening up other applications such as transportation.

Ideally, the PEFC system could be utilized as a cogeneration unit, with the waste heat utilized for its thermal value. At present, the low operating temperatures typically utilized $\left(80-90^{\circ} \mathrm{C}\right)$ preclude it from being used effectively in that capacity. Increasing the operating temperature would allow the low grade waste heat to be used more effectively, and, at the same time, possibly simplify the system and improve efficiency by reducing the effect of $\mathrm{CO}$ on the anode catalyst. Some increase in operating temperature could be possible even in present day PEFCs.

\section{Dispersed Power Generation}

It is becoming more difficult to obtain regulatory approval for large-scale power stations or to secure rights-of-way for high-tension power lines. Some proposed high-tension lines have met opposition due to their visual impact. The recent controversy about the biological effects of electromagnetic fields (EMF) has further contributed to public resistance to hightension lines and power substations. Perhaps it is not unreasonable to expect that a substantial amount of additional power capacity in this country may eventually be in the form of neighborhood or apartment building power stations that tap into the massive natural gas distribution grid. Fuel cells are ideal for this sort of application because of their high efficiency, low emissions and quietness. The South Coast Air Quality Management District (SCAQMD) in southern California has granted an emissions exemption to the ONSI PAFC power module following repeated demonstration of ultra-low emission levels. Though gas turbine systems by comparison are less expensive, it may be more cost effective to pay somewhat more for a fuel cell system and effectively bypass the full regulatory process and the associated costs.

For small entities to embrace the dispersed power generation concept there will probably need to be further incentive. Additional legislation to induce the demand-side generator to tie into the existing grid to sell excess capacity, for example, would make the investment more attractive.

Commercial and industrial facilities will probably take the lead in implementing fuel cell systems. It is becoming more common for small businesses that are either power intensive or are paying unusually high costs for their power to install their own generating capacity. As such, the commercial building and industrial sectors represent a large potential market for fuel cells. The Gas Research Institute (GRI) estimates that of this large population, approximately 18,000 MW should be economical for fuel cell cogeneration systems, provided the installed cost is $\$ 1,000 / \mathrm{kW}(6)$.

The industrial sector is similar to the commercial sector both in terms of its size as well as the characteristics required of the fuel cell. This market segment includes about 3,000,000 sites with about 20,000 of those accounting for over $90 \%$ of the energy use. Fifty per cent of the market is in the chemicals and primary metals industries. Approximately $10 \%$ of this potential market is for small (less than $1 \mathrm{MW}$ ) cogeneration systems. The PAFC and/or PEFC are expected to gain entry into this large market, provided that the performance and cost targets, which are similar to those described for the commercial sector, are met. Waste heat is at a premium in these applications, thus the PEFC must operate as a cogeneration system to be competitive. In both the commercial and industrial sectors the likely fuel in the near term will be natural gas, which will require high temperature reforming. Consequently, the systems issues related to thermal management of a PEFC stack with a high temperature reformer become important for these applications. 
The MCFC and SOFC technologies are not compatible with many of these applications. In contrast, the PAFC and the PEFCs are well suited for small, modular applications. Currently, appropriate PAFC technology has been commercialized. The present cost of a $200 \mathrm{~kW}$ PAFC unit (from ONSI) is approximately $\$ 2,500 / \mathrm{kW}$. GRI and the developers expect to reduce this cost to the target value of $\$ 1,000 / \mathrm{kW}$. The ONSI PC25 PAFC yields $200 \mathrm{~kW}$ of electric power and provides $760,000 \mathrm{Btu} / \mathrm{hr}$ of $74^{\circ} \mathrm{C}$ hot water. The electrical efficiency is $40 \%$ and the overall thermal efficiency (including heated water) is $85 \%$.

The PEFC, with its superior fuel cell performance, could readily emerge as a viable competitor to the PAFC technology for power production by offering the customer a lower life cycle cost. Ballard (originally in conjunction with Dow), is developing a $250 \mathrm{~kW}$ natural gas-fueled power plant after demonstration of a $10 \mathrm{~kW}$ plant (3). In order to compete effectively with the PAFC as cogeneration systems that would supply both electrical power and heating to a facility, the PEFC stack ideally would operate at a higher temperature than the typical $80^{\circ} \mathrm{C}$ to provide higher quality waste heat and possibly improve efficiency.

The PEFC may have some rather attractive features for this application. The PEFC is a low temperature system employing very benign materials, and has a pseudo-solid state structure. Compared with other low-temperature fuel cells, it has the advantages of employing distilled water rather than corrosive electrolytes, and to have a structure that easily enables pressurization, including differential pressurization. Pressurization, up to an optimized level indicated by overall energy efficiency considerations, can bring about significant enhancement of air cathode efficiency. Also, the power density obtained at an optimized working point for stationary power generation (about $0.7-0.8 \mathrm{~V}$ ) would be 2-3 times higher than that of the phosphoric acid fuel cell, and thus the foot-print of a PEFC stack will be significantly smaller. Compared with very high temperature cells such as MCFC or SOFC, the lower operating temperature of the PEFC has some clear advantages for smaller, more flexible systems. Much easier start-up/shut down would be possible, enabling surge power applications without the need to keep the stack continuously at a high temperature to be ready for use.

\section{Other Stationary Applications}

PEFCs could also find niche markets as power generation devices for rural cooperatives without ready access to grid connected electric power. Additionally, there could eventually be a large potential market as backup power to photovoltaic sources. Along the same vein, researchers in Europe are exploring a self-sufficient solar energy house that uses a $\mathrm{H}_{2} / \mathrm{O}_{2} \mathrm{PEFC}$ for reserve electric power (8). In another effort, a PAFC unit is being evaluated for operation on landfill biogas. A number of other renewable energy schemes may eventually become commercially viable. The economic benefits of using a fuel cell in these applications has not been seriously investigated.

An emerging market for fuel cells in general and PEFCs in particular is in uninterruptable power sources (UPS) for many large communication, computer and health care industries. In these situations, the fuel cell may operate continuously as the primary source of high quality DC and/or AC power, with the electric grid basically functioning as the backup to the fuel cells. Several such installations are being explored. The PEFC with its high efficiency and compact design fits this application well. The need for cogeneration is not important and these customers would be willing to pay a premium for high quality power. Such applications may be the first market entry of PEFCs for commercial applications.

\section{Coupling of a Natural Gas Reformer and a PEFC Stack}

Stable PEFC anode operation on a feed stream of natural gas reformate is a challenge that has to be met in order to enable utilization of PEFCs for stationary power generation. This challenge is more serious with the PEFC than with higher temperature systems because of the susceptibility of the anode to poisoning at even the $10 \mathrm{ppm} \mathrm{CO}$ level. Some of the problems associated with operation of PEFCs on realistic fuel feed streams have been addressed recently in the context of operation of PEFCs on methanol reformate. The roughly $1 \% \mathrm{CO}$ in a methanol reformate can be brought down to about $10 \mathrm{ppm}$ using shift reactors followed by a preferential oxidation reactor (PROX) utilizing a Pt/alumina catalyst (9). Unfortunately, the sensitivity of the PEFC to such residual levels of $C O$ $(10 \mathrm{ppm})$ is still very significant at the ordinary operation temperature of $80^{\circ} \mathrm{C}$. We have demonstrated, however, the ability to remediate effects of residual $\mathrm{CO}$ in the fuel feed stream by bleeding small levels of $\mathrm{O}_{2}$ or :ir into the anode compartment of the fuel cell $(10-\ldots$. There have been some recent indications of success by others in implementing this approach with PEFC stacks. We 
recently tested the oxygen bleeding approach for prolonged periods of time as part of our single cell testing activities and have experienced no difficulties with its extended application. Thus, a combination of: i) shift reactors to lower the roughly $10 \% \mathrm{CO}$ level of the methane reformate down to about $1 \%$, ii) air injection into a PROX reactor upstream of the fuel cell to lower the CO to the 1-10 ppm level, and iii) air bleeding into the anode to eliminate the residual $\mathrm{CO}$ effect, could conceivably provide fuel cell performance very nearly the equal of a neat hydrogen cell. The system is depicted in Fig. 1a. The overall loss of fuel caused by. the oxidative treatments in such a system should not exceed $4 \%$. While small, this is not trivial from a system efficiency perspective.

Several efforts, including our own with $\mathrm{Pt}-\mathrm{Ru} / \mathrm{C}$ catalysts (12), have indicated that some of the problems caused by residual $\mathrm{CO}$ within the anode can actually be solved by appropriate anode catalysts of sufficient $\mathrm{CO}$ electrooxidative activity. The identification of a $\mathrm{CO}$ tolerant catalyst would naturally have a significant impact on the design and efficiency of the system.

\section{Purifying Natural Gas Reformate with a Hydrogen Separator}

As discussed above, a major issue impacting the coupling of the PEFC with a methane reformer is the effect of contaminants, particularly $\mathrm{CO}$, on the fuel cell anode. A general approach to circumvent this difficulty is to utilize a gas separator of some form to supply pure hydrogen to the fuel cell. Not only does this eliminate the contamination difficulties, but it decouples to some extent the operation of the fuel processor and the fuel cell. The hydrogen feed to the fuel cell could be effectively dead-ended, as is done in a number of fuel cell systems that use neat hydrogen feed. This simplifies control of the complete system and allows, for example, stockpiling of hydrogen during low power demand. The fuel cell stack could then be brought up instantaneously with a "cold" reformer. These features would not be possible in a system that is coupled, as in the more conventional case (depicted in Fig. 1a) of using the anode effluent stream to heat the reformer (13).

Any means to purify the reformate stream will result in a retentate stream that is relatively rich in hydrogen, and contains $\mathrm{CO}$ and unreacted fuel. The general strategy is to use this retentate stream to fuel the reformer burner. A commercial hydrogen generator system offered by Haldor-Topsøe adopts such a strategy in that it uses the retentate from pressure swing adsorption (PSA) hydrogen purification columns to fuel a methanol reformer. Thus, the strategy and technology are proven and commercially viable, albeit not for a natural gas system.
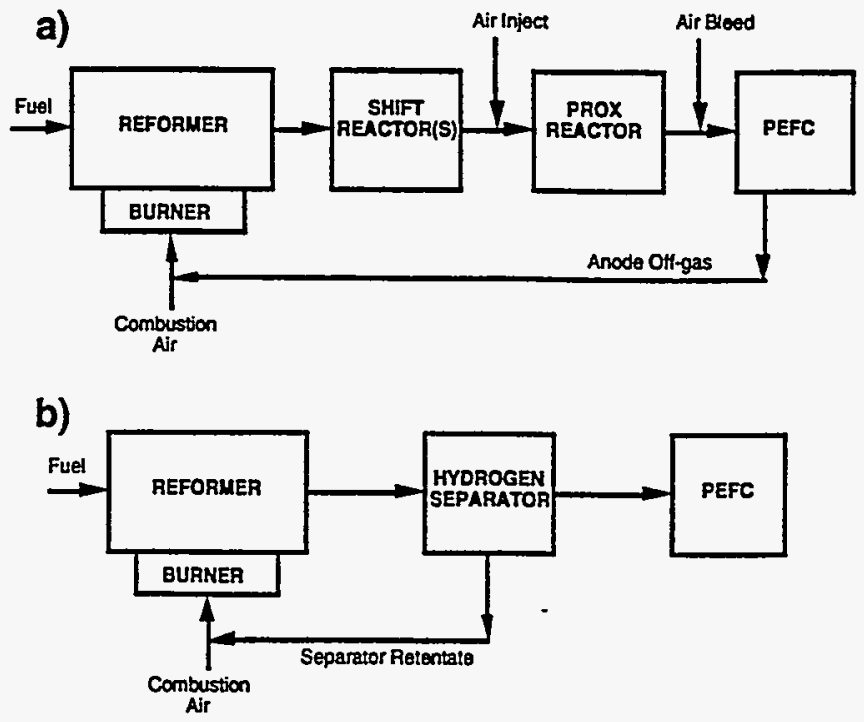

Fig. 1. Reformerffuel processors for PEFCs: a) a more conventional system with shift and PROX reactors and air injection at two points, and b) alternative concept incorporating a hydrogen permselective separator.

A more direct means than PSA of producing a pure hydrogen product is to use a permselective membrane reformer. In this manner, the hydrogen product is removed directly from the reactor through the hydrogen permselective reactor walls, which substantially enhances the conversion by shifting the reaction equilibrium towards the products. This scheme has been studied by a number of groups for some time, and looks promising for methanol reforming, but natural gas reforming introduces additional problems. For example, the higher temperatures necessary for methane reforming introduces membrane stability and longevity issues, and unless the steam/fuel ratio is unusually high, carbon formation is also a problem (14). While research in such systems is important, in the shorter term it may be more attractive to decouple the reactor and separator, and possibly even use some sort of reflux scheme.

A historical drawback with the use of a membrane separator module is cost. Commercial purifiers traditionally use $\mathrm{Pd} / \mathrm{Ag}$ films, either free-standing or supported on substrates. With such $\mathrm{Pd}$ based membranes, it is necessary to avoid exposure to 
hydrogen at low temperatures, otherwise phase changes of the Pd hydride may cause structural defects that compromise the integrity of the film.

Several groups are studying means of increasing the stability and lowering the Pd content of separator membranes. A fellow group at Los Alamos is developing Pd clad Ta films (15). Tantalum supplies phase and structural stability while still providing high hydrogen permeability. The Pd is applied to either face of the $\mathrm{Ta}$ film to facilitate the interfacial processes. At this point, the total $\mathrm{Pd}$ loading is only about $1 \mathrm{mg} \mathrm{Pd} / \mathrm{cm}^{2}$ of separator membrane. We have operated a $5 \mathrm{~cm}^{2}$ single cell PEFC on the permeate of a $4 \mathrm{~cm}^{2}$ membrane separator operating at $315^{\circ} \mathrm{C}$ with a pseudo-methanol reformate feed $\left(1 \% \mathrm{CO}, 24 \% \mathrm{CO}_{2}\right.$, $74 \% \mathrm{H}_{2}$ ). Fig. 2 indicates that about $600 \mathrm{~mA} / \mathrm{cm}^{2}$ is obtained at $0.6 \mathrm{~V}$. In contrast, only $100 \mathrm{ppm}$ of $\mathrm{CO}$ (in $\mathrm{H}_{2}$ ) fed directly to the anode suppressed the current density at this voltage to about $60 \mathrm{~mA} / \mathrm{cm}^{2}$, one-tenth the cell performance on the permeate, as is also shown in Fig. 2. It is anticipated that the separator will be equally effective with the much higher $\mathrm{CO}$ levels expected from a natural gas reformer. The membrane separator development is ongoing and improvements in throughput and lowering of the Pd loadings are constantly being realized.

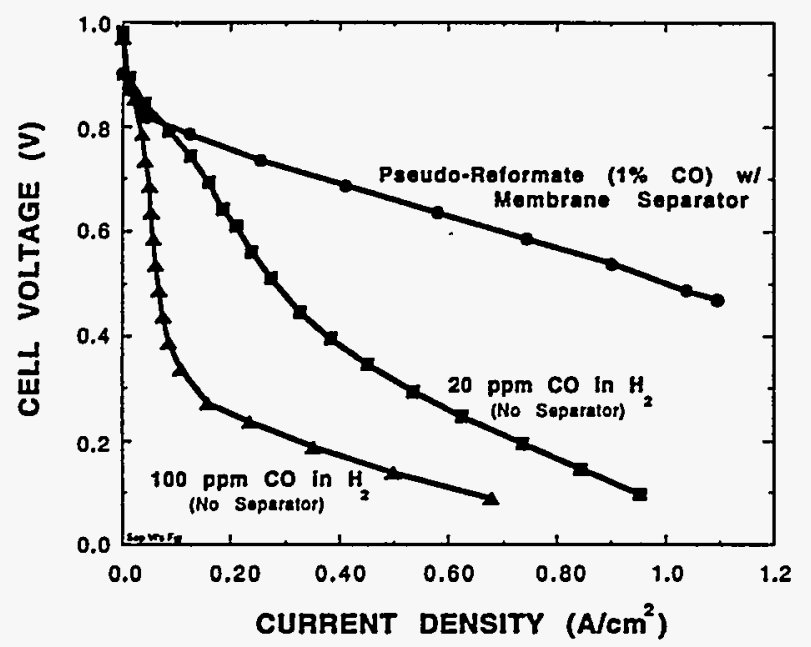

Fig. 2. Polarization curves depicting a single cell PEFC operating at $80^{\circ} \mathrm{C}$ on i) pseudo-reformate $(1 \% \mathrm{CO})$ fed via a high throughput hydrogen permselective separator, ii) $20 \mathrm{ppm} \mathrm{CO}$ in hydrogen, and iii) $100 \mathrm{ppm} C O$ in hydrogen.

Preliminary process simulations for the reformer/separator/fuel cell scheme depicted in Fig. $\mathrm{lb}$ are quite promising, particularly for the methanol- fueled system, while the natural gas-fueled system is more problematic. In the latter system, higher steam/fuel ratios are required and higher $\mathrm{CO}+\mathrm{CO}_{2}$ concentrations are obtained in the typical steam reformer. This combination suppresses the partial pressure of hydrogen and severely decreases the effectiveness of the separator because, at best, the partial pressures of hydrogen on either side of the separator are equal. It is necessary to increase the hydrogen partial pressure in the reformate in some manner. Possible approaches are i) condense out the reformate product water before the separator, ii) pressurize the reformer substantially above $3 \mathrm{~atm}$ (some commercial tubular reformers operate at $20 \mathrm{~atm}$ or more (16), or iii) introduce a vacuum/compressor pump downstream of the separator. The latter is probably the most preferable because the reformer reaction equilibrium favors the products at lower pressures and also because "compressors" are usually more efficient at lower pressures. Furthermore, the same pump could be used to pressurize a storage/surge vessel. Lastly, the response of the vacuum pump is faster and the system is simpler from a control perspective than with the use of a highly pressurized reformer, or a family of heat exchangers, as in the first option.

If a permselective separator is paired with a methanol reformer in the most effective way, the high and low temperature shift and partial oxidation reactors would not be needed because a roughly $1 \%$ $\mathrm{CO}$ reformate product is useful as burner fuel. In the case of the natural gas reformer, the $\mathrm{CO}$ content will be an order of magnitude higher (13), so the most efficient reformer/separator system may conceivably consist of an initial separator module after the reformer that removes the majority of hydrogen, then the retentate is fed to a shift reactor to convert a large fraction of the $\mathrm{CO}$ to hydrogen (the equilibrium shift arising from the $\mathrm{H}_{2}$ removal will make the conversion more complete than usual). A second separator module then collects whatever remaining hydrogen is recoverable beyond that needed to fuel the reformer burner. In general, a number of system configurations are possible and will need to be explored to determine the most cost effective and efficient approach.

\section{Low Cost Stack Components}

With a target of only $\$ 1,000 / \mathrm{kW}$, a PEFC stationary power plant will require relatively low cost fuel cell stacks because the power conditioning and natural gas reforming elements alone will contribute significantly to the costs. At Los Alamos, we are experimenting 
with the scale-up and automated fabrication of the low platinum loading catalyzed membranes that we developed based on "thin-film" catalyst layers $(17,18)$. Further work concentrates on the development of lowcost gas diffusion backing, flow-field and bipolar plate materials. One promising flow-field scheme consists of off-the-shelf stainless steel screens. Researchers elsewhere (19) have reported the use of stainless steel with no corrosion after 1000 hours of testing. However, we anticipate some form of surface treatment will be required.

\section{Conclusions}

The PEFC is emerging as a compact, highly efficient and potentially cost-effective system. The performance of the PEFC is better than that of the PAFC in terms of operating voltage (conversion efficiency) at the same current density. Manufacturing costs of PEFCs are expected to be comparable to or lower than PAFC systems, thus, the PEFCs may be a better option than PAFCs for some utility and demand-side niche markets. The market size is large if it assumed that it comprises approximately $5 \%$ to $10 \%$ of the following markets i) public utility power generation, ii) cogeneration for commercial buildings, iii) cogeneration for industrial applications, and iv) quality DC power for telecommunications, computer and healthcare industries.

One of the difficulties with coupling a PEFC with a natural gas reformer is the susceptibility of the anode to $\mathrm{CO}$ and/or other contaminant poisoning. Several strategies can be adopted to alleviate this difficulty, and one that we are suggesting as worthy of furtherstudy is purifying the reformate using a hydrogen permselective separator. This scheme is quite attractive, provided efforts to substantially lower the cost of the separator module are ultimately successful. On a single cell level, we have operated a PEFC on the membrane separator permeate of a pseudo-reformate feed with $1 \% \mathrm{CO}$.

\section{Acknowledgments}

R. K. Sen of R. K. Sen and Associates, Washington, D. C., assimilated some of the marketing data. Nathaniel Peachey and Robert Dye of MST-7 at Los Alamos provided the membrane separator and assisted in coupling it with the fuel cell. Funding was provided by two program offices within the Department of Energy, the Office of Transportation Technology and the Hydrogen Program of the Office of Utility Technologies.

\section{References}

1. Prater, K. B. J. Power Sources, 1994, 51, 129.

2. Landgrebe, A; Gottesfeld, S. Extended Abstracts, Electrochemical Society Meeting, Vol. 94-2, Miami Beach, FL, Oct., 1994, Abstract No. 604, p. 944.

3. Watkins, D. S.; Peters, B.C. Program and Abstracts of the Fuel Cell Seminar, San Diego, CA, Nov. Dec., 1994, p. 250.

4. Impact of Fundamental Technical Improvement., GRI Report No. GRI-89/0137, International Fuel Cells Corporation, 1989.

5. The Financial and Strategic Benefits of Fuel Cell Power Plants, Vols. I \& II, EPRI Report No. EPRI EM-4511, Temple, Parker \& Solane, Inc., 1986.

6. Trimble, K.; Woods, R. J. Power Sources, 1990, 29, $37-45$.

7. Serfass, J. A. J. Power Sources, 1990, 29, 119-130.

8. Stahl, W.; Voss, K.; Goetzberger, A. Solar Energy, 1994, 52, 111.

9. Vanderborgh, N.E.; Guante, J.; Dean, R.E.; Sutton, R.D. Program and Abstracts of the Fuel Cell Seminar, Long Beach, CA, Oct. 1988, p. 52.

10. Gottesfeld, S. U.S. Patent No. 4,910,099 1990.

11. Gottesfeld, S.; Pafford, J. J. Electrochem. Soc. 1988, 135, 2651-2652.

12. Wilson, M.S.; Derouin, C.R.; Valerio, J.A.; and Gottesfeld, S. Proc. 28th Intersoc. Energy Conv. Eng. Conf. (IECEC), Atlanta, GA, Aug., 1993, p. 1.1203.

13. Multi-Fuel Reformers for Fuel Cells Used in Transportation, DOE Report No. DOE/CE/503432, Arthur D. Little, Inc., Cambridge, MA, 1994.

14. Jorgensen, S.L.; Nielsen, P.E.H.; Lehrmann, P. Catalysis Today, 1995, 25, 303-7.

15 Peachey, N. M.; Snow, R.C.; and Dye, R.C. J. Memb. Sci., To be Published.

16. Dybkjaer, I. Fuel Proc. Tech., 1995, 42, 85-107.

17. Wilson, M. S.; Gottesfeld, S. J. Appl. Electrochem., 1992, 22, 1-7.

18. Wilson, M. S.; Valerio, J. A.; Gottesfeld, S. Electrochim. Acta, 40, 355 (1995).

19. Mallant, R.K.A.M.; Koene, F.G.H.; Verhoeve, C.W.G.; Ruiter, A. Program and Abstracts of the Fuel Cell Seminar, San Diego, CA, Nov. - Dec., 1994, p. 503. 


\section{DISCLAIMER}

This report was prepared as an account of work sponsored by an agency of the United States Government. Neither the United States Government nor any agency thereof, nor any of their employees, makes any warranty, express or implied, or assumes any legal liability or responsibility for the accuracy, completeness, or use. fulness of any information, apparatus, product, or process disclosed, or represents that its use would not infringe privately owned rights. Reference herein to any specific commercial product, process, or service by trade name, trademark, manufac: turer, or otherwise does not necessarily constitute or imply its endorsement, recommendation, or favoring by the United States Government or any agency thereof. The views and opinions of authors expressed herein do not necessarily state or reflect those of the United States Government or any agency thereof. 